Hydrol. Earth Syst. Sci., 18, 1251-1263, 2014

www.hydrol-earth-syst-sci.net/18/1251/2014/

doi: 10.5194/hess-18-1251-2014

(C) Author(s) 2014. CC Attribution 3.0 License.

\title{
Impacts of climate variability on wetland salinization in the North American prairies
}

\author{
U. Nachshon ${ }^{1}$, A. Ireson ${ }^{1}$, G. van der Kamp ${ }^{2}$, S. R. Davies ${ }^{3}$, and H. S. Wheater ${ }^{1}$ \\ ${ }^{1}$ School of Environment and Sustainability and the Global Institute for Water Security, University of Saskatchewan, \\ 11 Innovation Boulevard, Saskatoon, Saskatchewan, S7N 3H5, Canada \\ ${ }^{2}$ Environment Canada, 11 Innovation Boulevard, Saskatoon, Saskatchewan, S7N 3H5, Canada \\ ${ }^{3}$ Imperial College London, Department of Civil and Environmental Engineering, London, UK
}

Correspondence to: U. Nachshon (unachshon@gmail.com)

Received: 10 October 2013 - Published in Hydrol. Earth Syst. Sci. Discuss.: 8 November 2013

Revised: 10 February 2014 - Accepted: 17 February 2014 - Published: 1 April 2014

\begin{abstract}
The glaciated plains of the North American continent, also known as the "prairies", are a complex hydrological system characterized by hummocky terrain, where wetlands, containing seasonal or semi-permanent ponds, occupy the numerous topographic depressions. The prairie subsoil and many of its water bodies contain high salt concentrations, in particular sulfate salts, which are continuously cycled within the closed drainage basins. The period between 2000 and 2012 was characterized by an unusual degree of climatic variability, including severe floods and droughts, and this had a marked effect on the spatial distribution, water levels and chemical composition of wetland ponds. Understanding the geochemical and hydrological processes under changing environmental conditions is needed in order to better understand the risk and mitigate the impacts of future soil and water salinization.

Here we explore salt dynamics in the prairies using field observations from St. Denis, Saskatchewan, taken mostly over the last 20 years. Measurements include meteorological data, soil moisture, soil salinity, groundwater levels and pond water volume, salinity, and chemical composition. The record includes periods of exceptional snow $(1997,2007)$ and periods of exception rainfall $(2010,2012)$, both of which resulted in unusually high pond water levels. Measurements indicated that severe pond salinization only occurred in response to extreme summer rainfall. It is hypothesized that since rainfall water infiltrates through the soil towards the depressions, while snowmelt water flows mainly as surface water over frozen soils, they have markedly different impacts on salt transport and pond salinization. Whilst this hypothesis is
\end{abstract}

consistent with our conceptual understanding of the system, it needs to be tested further at a range of field sites in the prairies.

\section{Introduction}

Surface water and shallow groundwater salinization is a problem affecting agriculture, water resources and ecosystem health in many areas of the world, including Australia (Dehaan and Taylor, 2002; Rengasamy, 2006), the Aral Sea region (Micklin, 2007), playas and sabkhat environments (Tyler et al., 2006) and many other areas (Rengasamy, 2006). Salt dynamics are driven by hydrological processes, which cycle seasonally but also change over long timescales as a result of climate variability and change, and changes in land use and land management practices. The physical mechanisms that lead to salinization operate in different ways in different areas, largely as a function of local climatological, hydrological and geological conditions.

This paper takes the salt-rich glaciated plains of North America, known as the prairie pothole region, as a case study to explore how recent climate variability has dramatically affected the salinity of ponds. The pothole region spreads from Alberta, Saskatchewan and Manitoba in Canada, through Montana and the Dakotas in USA. The landscape is characterized by hummocky terrain, where wetlands and ponds occupy the ubiquitous depressions (Winter, 1989; van der Kamp and Hayashi, 2009). The region supports a diverse community of wildlife species and major 
agricultural industry that are highly sensitive to the hydrological conditions (Wienhold and van der Valk, 1989). Hydrological processes in the region are complex and unusual, characterized by closed basins isolated from any regional drainage network, with drainage via a spill and fill sequence into terminal ponds (Shook and Pomeroy, 2011). Snowmelt runoff from surrounding uplands and precipitation on the wetlands are the dominant hydrological inputs into the wetland systems, together with occasional runoff events due to high-intensity rainfall, whereas snow distribution over the landscape is an important control on the hydrology (Shaw et al., 2012; Spence and Woo, 2003); semi-arid conditions result in minimal shallow groundwater recharge from uplands, while ponds drain to shallow groundwater beneath the depressions (van der Kamp and Hayashi, 2009).

Some of the past studies (e.g. Swanson et al., 1988; Euliss et al., 2004) suggested that the regional groundwater flow in deep aquifers is the major mechanism to impact salt transport and accumulation in the prairie pothole region. However, other studies (e.g. Hayashi et al., 1998b; Berthold et al., 2004; Heagle et al., 2013; Nachshon et al., 2013) suggest that shallow subsurface hydrological processes play a key role in salt transport. Nachshon et al. (2013), based on previous work (e.g. Keller et al., 1991; Hayashi et al., 1998b; Berthold et al., 2004; Heagle et al., 2013), presented a conceptual model to describe the major salt dynamics occurring within the glacial till portion of the prairies under various land use and climatic conditions. The authors suggested that for wet climatic conditions associated with extremely snowy winters, the impact on pond salinization would be minimal since snowmelt water flows as surface water over frozen soil, with minimal dissolution and transport of subsurface salts from the uplands to the ponds. On the contrary, for rainassociated wet conditions most of the water infiltrates and carries salts from the subsurface of the uplands towards the depressions which contain the ponds.

In humid environments, streamflow is an integrated variable that aggregates the effect of the climatic boundary conditions and the land use/management-mediated hydrological processes occurring within the watershed (Wheater et al., 1993). In the pothole region, where there is often no regional streamflow, these factors are expressed in the pond storage, and therefore studying the ponds is a good way to understand the system sensitivity to a particular change. This work explores changes of pond salinity using a 20-year record of observations from a field site in the Canadian prairies, which in the past decade has been subject to extremely variable climatic conditions - including both extreme droughts and floods. In particular, this study explores the impacts of extreme precipitation on salinity, considering separately summer rainfall and winter snowfall. The impetus for the work came from the observation that, as the water level and volume increased during recent extreme wet conditions, there was a marked increase of the salinity of the water in some ponds - the opposite of the dilution that one might naively expect.

\section{Methods}

In this work extreme rain and snow conditions will be examined with respect to their impact on salt transport, salt accumulation and wetland salinization. Salinization processes are studied at field scale by examining changes in pond salinity throughout the entire site; at the pond scale by observing a specific pond with a high temporal resolution, and along a transect connecting two neighboring ponds with high temporal and spatial resolution.

\subsection{Field site}

The field site is located at the St. Denis National Wildlife Area (NWA) $\left(106^{\circ} 05^{\prime} 0.20^{\prime \prime} \mathrm{W}, 52^{\circ} 12^{\prime} 31.32^{\prime \prime} \mathrm{N}\right)$, approximately $40 \mathrm{~km}$ east of Saskatoon, Saskatchewan, Canada (Fig. 1a). The St. Denis area has a hummocky topography and is underlain by a clayey glacial till, with typical hydrogeology for the glacial till portion of the prairies (Hayashi et al., 1998a). The main part of this study focuses on ponds 107, 108A, and 109 (Fig. 1). Pond 109 is a semi-permanent pond, i.e. the pond remains wet all year for most years. Ponds 107 and $108 \mathrm{~A}$ are ephemeral ponds that dry out by the end of most summers. Most of the area is cultivated, with the exception of the area to the north of pond 109 which is a natural grassland, and the numerous wetlands (that is, the ponds and their riparian zones). Pond 109 has a substantial riparian zone with a willow ring with a width of $\sim 10 \mathrm{~m}$ around the pond, covered by trembling aspen trees, balsam poplar and willows rising up to $\sim 8 \mathrm{~m}$. The willow rings around ponds 107 and 108A are minor compared to those around pond 109 , with a width of $1-2 \mathrm{~m}$, and covered mainly by cattails (Typha) rising up to $\sim 1.5 \mathrm{~m}$. A surface runoff flow path exists from ponds 107 through pond 108A to pond 109, and pond 109 can be considered as the terminal pond of this local watershed, at least with respect to surface runoff.

\subsection{Precipitation data}

Precipitation data used in this study are from the nearest climate station with continuous records from 1993 to 2012 (Table 1), the Saskatchewan Research Council Saskatoon climate reference station (Beaulieu and Wittrock, 2013) at Saskatoon about $35 \mathrm{~km}$ west of the St. Denis site. The data are presented as cumulative amounts of summer rain (April-September) and winter precipitation (OctoberMarch), mostly snow. The winter data are not corrected for the wind undercatch effect, for example as described by Mekis and Vincent (2011). Comparison with the corrected precipitation data, available to 2007 , indicates that the actual winter precipitation is underreported by $\sim 40$ to $50 \%$. However, for the purpose of this paper these readings are 

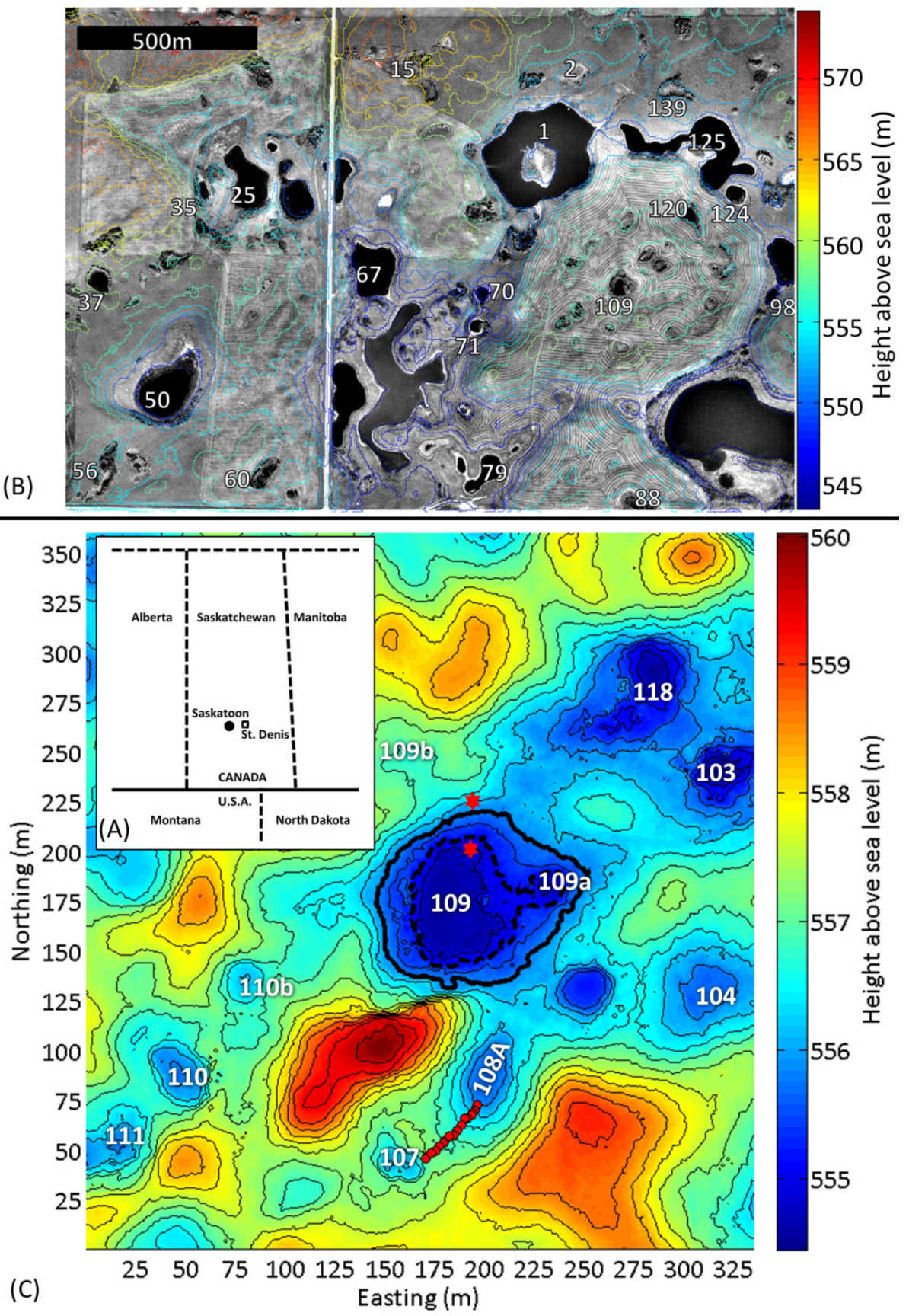

Fig. 1. (A) Regional location of the St. Denis National Wildlife Area; (B) St. Denis NWA site; (C) enlargement of pond 109 area. In (C) the dots between pond 107 and 108A indicate the location where salinity and groundwater levels were measured along the transect. Stars represent piezometers; the thick solid line around pond 109 indicates the water margin of the pond in July 2012; the dashed line at pond 109 indicates the average location of the pond 109 water margin. White numbers indicate selected ponds.

sufficient to indicate inter-annual variability; the focus is on the differences between the reported winter precipitation in every year (from the autumn of previous year (October) to the spring of the reported year (March)) and the long-term average.

\subsection{Groundwater and surface water data}

Groundwater levels at a number of piezometers scattered throughout the site have been measured (archived data of Environment Canada). For this work, data from piezometers 94W7 (hereafter the "upland piezometer") and 802P1 (hereafter the "pond piezometer") were used (Fig. 1c). The 
Table 1. Measurements locations, periods, and temporal resolutions.

\begin{tabular}{llll}
\hline Property measured & Location of measurement & Measurement period & Temporal resolution \\
\hline Precipitation (rain + snow) & Saskatoon & 1993-2012 & continuous hourly \\
Rain & St. Denis & 5-24 Jul 2012 & continuous hourly \\
Groundwater levels & St. Denis & 1997-2012 & continuous daily/hourly \\
Pond 109 depth & St. Denis & $1968-2012$ & continuous monthly \\
Ponds salinity & St. Denis & 2009-2012 & sporadic monthly \\
Pond 109 salinity & St. Denis & $1993-2012$ & continuous monthly/weekly \\
Pond 109 chemical composition & St. Denis & 2007-2009, 2012 & sporadic monthly \\
Mini-observation wells & St. Denis & Jul 2012 & continuous weekly/daily \\
EM-38 & St. Denis & 24 Jul 2012 & one time \\
\hline
\end{tabular}

upland piezometer, located north of pond 109 , is screened from $1.8-5.3 \mathrm{~m}$ b.g.l. (below ground level) and the pond piezometer, located within pond 109 , is screened from 5.8$7.6 \mathrm{~m}$ b.g.l. Hydraulic heads in the piezometers were measured continually from 1997 to 2012, on a daily basis (Table 1). The depth at the deepest point of pond 109 was measured manually on a monthly basis during the summers from 1968 to the present (Conly et al., 2004). Vertical hydraulic gradients between the pond piezometer and the pond water were small. Here, a continuous pond-water-level time series was constructed from 2007 onwards by using the daily logged piezometer data to temporally infill between the monthly manual surface water level measurements. The pond's water volume $V\left(\mathrm{~m}^{3}\right)$ was computed based on the work of Hayashi and van der Kamp (2000):

$V=1420 h^{2.24}$,

where $h$ is the depth of water at the centre of the pond. These authors limited and validated Eq. (1) for maximal $h$ of $1.2 \mathrm{~m}$, since that was the deepest measurement of the water pond depth at that time. Since over recent years deeper pond water levels were recorded, the original bathymetric survey data of Hayashi and van der Kamp (2000), which is archived at Environment Canada, was used to compute $V$ for $1.2<h<1.8 \mathrm{~m}$ and to revalidate Eq. (1) for these depths. It was found (data not shown) that Eq. (1) is valid for these depths with errors smaller than $5 \%$.

\subsection{Pond water salinity}

Electrical Conductivity (EC) was measured at 14 ponds at St. Denis (Fig. 1b) several times a year during the summer months from 2009 to 2012 (Table 1). In addition, in pond 109 EC measurements were taken every few weeks in the summer months from 1993 to 2012 (Table 1).

Major ion analysis was conducted annually for pond 109 water from 1994 to 2009, and in 2012. Data from 2007 to 2009 and 2012 are used in this study (Table 1).

Pond 109 EC and volume measurements permit an estimate of the mass of dissolved salts $\left(M_{\text {salt }}\right)(\mathrm{kg})$ in the water, based on an approximate relationship between EC and dissolved salt mass (Rhoades et al., 1996):

$M_{\text {salt }}=0.00064 \cdot \mathrm{EC} \cdot V$,

where $M_{\text {salt }}$ is in $\mathrm{kg}, \mathrm{EC}$ is in $\mu \mathrm{S} \mathrm{cm}^{-1}$ and $V$ is in $\mathrm{m}^{3}$.

\subsection{Transect measurements}

Spatially detailed manual measurements of EC and water levels along a transect from pond 107 to pond 108A were obtained over a rainy 25-day period in July 2012 (Table 1). A series of 16 mini-observation wells were installed to measure shallow water table changes beneath the upland between pond 107 and 108A (Fig. 1c). The transect was located along the shortest path between the ponds, in the lowest part of the landscape. The spill elevation of pond 107 is approximately $1 \mathrm{~m}$ higher than that of pond 108A and the lateral distance between the ponds is $35 \mathrm{~m}$. Each mini-observation well consists of a PVC tube, $75 \mathrm{~cm}$ long, inner diameter of $1.27 \mathrm{~cm}$, perforated along its entire length. Each tube's lower end was sealed and they were inserted into the ground by direct push, to a depth of $\sim 60 \mathrm{~cm}$. Water levels in the miniobservation wells were measured manually with a ruler and EC measurements were taken in situ by a portable EC probe (Cole-Parmer, 1481-60, Canada). These measurements were taken on 5, 6, 11, 19 and 24 July. During this period, precipitation (rain) measurements were taken hourly at the climate station located within the St. Denis field site (operated by Environment Canada). In addition, on 24 July an EM38 probe (Geonics Ltd, Canada) was used to measure soil EC around pond $108 \mathrm{~A}$ and pond 109 . Measurements were taken at $1 \mathrm{~m}$ intervals along the pond's edge. Since the EM38 readings are sensitive both to water content and salinity, calibration had to be done to obtain an estimate of pore water EC. Since the soil around the pond is fully saturated, it was assumed that the changes in the EM38 readings were due to salinity differences. Manual EC measurements of the pore water at specific points around the pond were taken using the EC probe, and these data were used to calibrate the EM38 readings. 

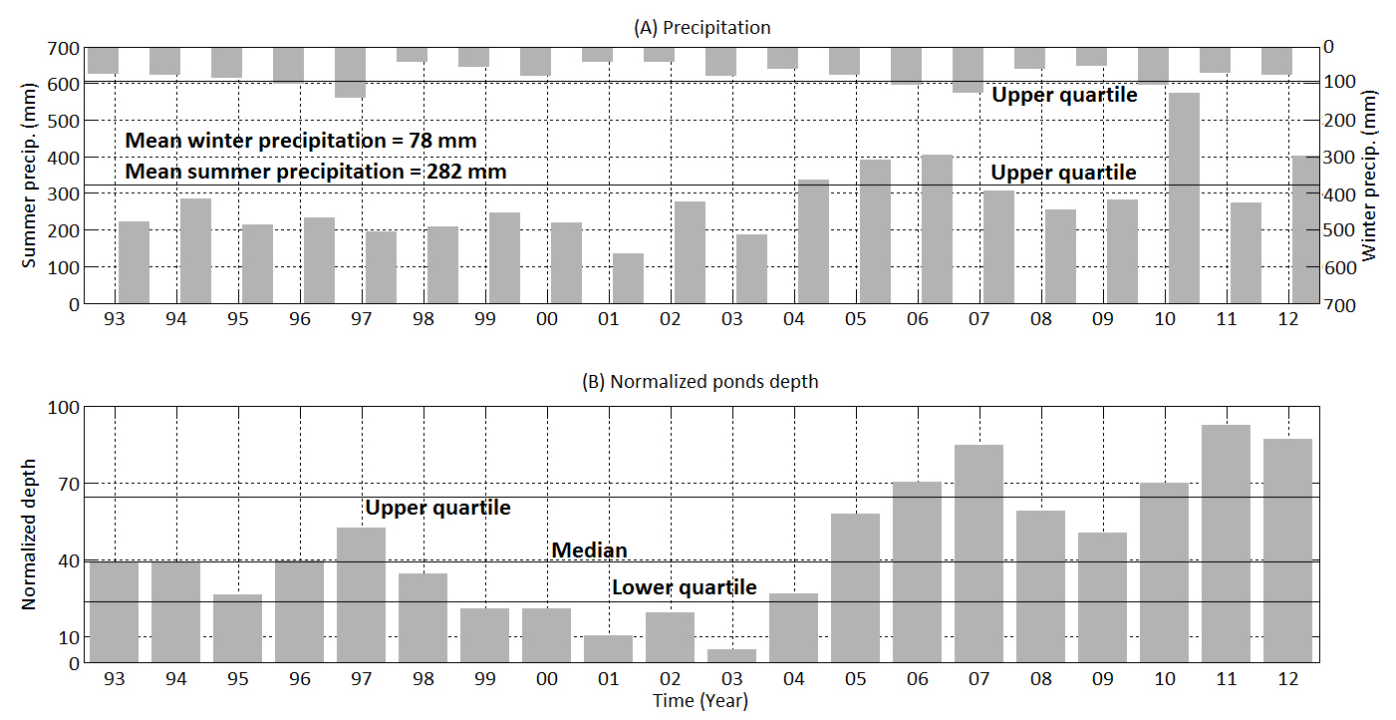

Fig. 2. (A) Total summer rainfall plus winter snow per hydrologic year. (B) Averaged and normalized depths of 12 ponds at St. Denis.

\section{Results and discussion}

\subsection{Field scale changes in pond water levels}

In the prairies, changes in pond storage are a response to a large number of often confounding processes, including rainfall amount, timing and intensity, snow spatial distribution and amount, timing of snowmelt, the spatiotemporal pattern of surface runoff versus infiltration (strongly affected by soil freeze-thaw processes, as well as land use), and the spatiotemporal pattern of evapotranspiration (again strongly affected by land use). A particularly important factor is prefreeze of soil moisture content: if the soils are very wet then when they freeze they have a very low infiltration capacity, and hence runoff over frozen soils during the subsequent melt period is more intense. This mechanism explains the widespread flooding in Saskatchewan and Manitoba in 2011, which was attributed to high rainfall in the summer of 2010 (see Fig. 2), leading to high antecedent soil moisture. Another factor is the timing of snowfall and accumulation. Earlier snowfall means that the relatively warm soils are more effectively insulated, and hence the extent of soil freezing is less, and a larger proportion of snowmelt is expected to go to infiltration versus runoff. This discussion serves to demonstrate that the hydrological processes in the prairies are highly complex, and rainfall-runoff type of responses that apply elsewhere, do not tend to work in this environment. Figure 2 contrasts summer and winter precipitation (Fig. 2a) with an integrated measure of annual maximum pond level across the site (Fig. 2b). The pond level measurement was calculated by taking the mean of the normalized depths of 12 ponds (ponds 1, 2, 20, 25, 26, 35, 36, 37, 50, $60,109,120$ ). Each pond depth time series (limited to the open-water season) was normalized by dividing the depth by
Table 2. Factors influencing the pond levels during wet conditions.

\begin{tabular}{ccccc}
\hline Year & $\begin{array}{c}\text { High } \\
\text { pond } \\
\text { level } \\
\text { in } \\
\text { previous } \\
\text { year }\end{array}$ & $\begin{array}{c}\text { High } \\
\text { summer } \\
\text { rainfall } \\
\text { in } \\
\text { previous } \\
\text { year }\end{array}$ & $\begin{array}{c}\text { High } \\
\text { winter } \\
\text { snowpack }\end{array}$ & $\begin{array}{c}\text { High } \\
\text { summer } \\
\text { rainfall } \\
\text { in } \\
\text { current } \\
\text { year }\end{array}$ \\
\hline 2006 & X & X & X & X \\
2007 & X & X & X \\
2010 & X & X & & X \\
2011 & X & & & \\
2012 & & & & \\
\hline
\end{tabular}

the maximum depth observed in the period 1993-2012. The fact that the averaged level is never $100 \%$ indicates that different ponds reached their maximum level in different years. For the purposes of this discussion, water levels of $70 \%$ and above are assumed to represent unusually wet conditions, and these were observed in 2006, 2007, 2010, 2011 and 2012. It is clear from Fig. 2 that there is a considerable delay before precipitation extremes are translated into responses in the pond levels, and also that there is a different sensitivity to snow versus rainfall. For all of the wet years, this is summarized, qualitatively, in Table 2. It is also useful to this discussion to consider the years 1994, when current and antecedent conditions were at or slightly below the average for the period of record, and 1997, where the snowpack was deepest, and the pond levels were high, though not up to the $70 \%$ threshold. 


\subsection{Field scale changes in pond salinity}

Salinity of ponds in the prairies is highly variable (Euliss et al., 2004). Stewart and Kantrud (1972) and Millar (1976) distinguished between freshwater ponds (EC, $<500 \mu \mathrm{S} \mathrm{cm}^{-1}$ ), moderately brackish ponds (EC between $500-5000 \mu \mathrm{S} \mathrm{cm}^{-1}$ ) and brackish-saline ponds $\left(\mathrm{EC}>5000 \mu \mathrm{S} \mathrm{cm}^{-1}\right)$. The reasons for these differences in salinity are understood to be a function of how the ponds interact with the groundwater and surface runoff. Fresh "recharge" ponds lose water to groundwater, brackish-saline "discharge" ponds gain water from groundwater and surface water (Nachshon et al., 2013), and the moderately brackish ponds are a more complex combination of input and output of surface and subsurface water of various degrees of salinity. The St. Denis field site is only $1.6 \times 2.4 \mathrm{~km}$, yet contains ponds with salinities that cover this entire spectrum. To examine the impact of wet conditions on pond salinity, EC measurements from 14 ponds at St. Denis were taken from 2009 to 2012, shown in Fig. 3. A longer record from only one pond is explored in more detail below. There is an almost completely consistent pattern in the response, with freshwater ponds (in 2009) becoming salinized over the wet period from 2010 onwards, brackish-saline ponds becoming diluted, and moderately brackish ponds having relatively stable $\mathrm{EC}$ values. The only significant anomaly to this pattern is in pond 70 in 2010, which we cannot explain. The water flushed into the ponds may have a varying salinity over the landscape in the different ponds, but the fact that the salinity of moderately brackish ponds did not change dramatically suggests that the salinity of this water which entered the ponds is of a similar salinity to the brackish pond water, an EC of 2000 to $3000 \mu \mathrm{S} \mathrm{cm}^{-1}$. Therefore note that while the brackish ponds are diluted, there may still be a considerable mass input of salt into the ponds. Heagle et al. (2013) showed this for pond 50 (a brackish-saline pond, see Fig. 3), where from 2009 to 2011 the mass of $\mathrm{SO}_{4}$ in the pond water increased by more than $50 \%$ whilst the EC reduced by $\sim 20 \%$. Overall, the data in Fig. 3 suggest that most or all the ponds in the landscape were enriched in salt mass under wet conditions, assuming that the pond volumes increased over the wet conditions period, as indicated by Fig. 2b.

Ponds 60 and 117 are freshwater ponds that maintained a relatively constant EC over the period 2009-2012, in contrast to all of the other freshwater ponds where an increase in EC was observed (Fig. 3). Ponds 60 and 117 are the highest and most isolated ponds in the site, and unlike all the other freshwater ponds, they do not have higher-elevation ponds adjacent to them, from which they may receive salts, by surface or subsurface pathways.

\subsection{Changes in water level in a terminal recharge pond}

Pond 109 at St. Denis is a terminal recharge pond (i.e. it collects surface water but does not spill, and loses water and

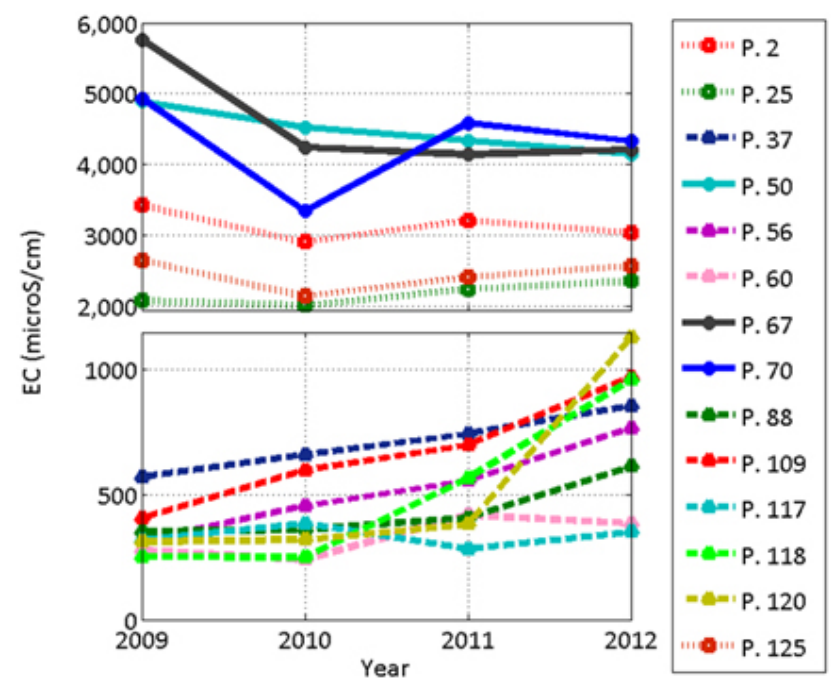

Fig. 3. Averaged EC of selected ponds in the St. Denis NWA from 2009 to 2012. Solid, dot, and dashed lines indicate brackish-saline, moderately brackish, and freshwater wetlands, respectively.

salt to groundwater), which is well studied, with a long-term archived data set. Figure 4 presents pond 109 water depths from 1969 to 2012 . A depth of $1.27 \mathrm{~m}$ (70\% of the deepest recorded pond depth, shown in Fig. 4) was used to indicate unusually wet conditions. Consequently, and in good agreement with the precipitation data and the regional pond depths (Fig. 2), wet conditions in pond 109 persist in 1997, 2007 and 2010-2012. A distinct difference between the wet conditions associated with snowy winters $(1997,2007)$ and rainy summers $(2010,2012)$ is observed. In wet years associated with snowy winters, as in non-wet years, the pond maximal depths occurred in springtime, following the snowmelt. For wet years associated with rainy summers, the pond water levels continually rose up from spring to late summer. In 2010, pond levels rose from June to September due to very heavy rain (Fig. 2a). The year 2012 also had high water levels throughout the entire summer from March to October, with positive increases in the pond level from March to July. For 2011, as indicated in Table 2, the high water levels were due to the high antecedent water storage from 2010, with the (unexceptional) snowmelt event superimposed on this to produce what were then unprecedented water levels. This unprecedented pond level was matched and slightly exceeded in 2012, this time due to high summer rainfall.

\subsection{Changes in salinity in a terminal recharge pond}

EC measurements for pond 109 have been taken since 1993, excluding the drought years (1999-2004) when the pond dried out completely, and 1995 and 2006 due to logistical problems. Figure 5a presents pond 109 estimated pond water volume, based on the depth-volume relationship in Eq. (1); Fig. 5b measured pond water EC and estimated dissolved salt 


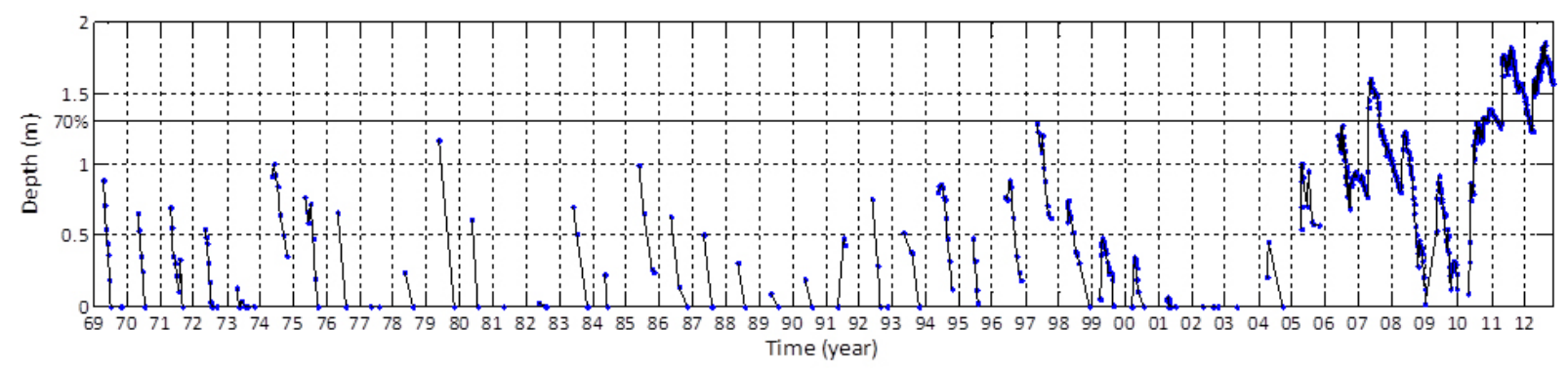

Fig. 4. Pond 109 water depths from 1969 to 2012.

mass based on Eq. (2); and Fig. 5c changes in pond volume, $\mathrm{EC}$, and salt mass over selected summer periods.

It can be seen that until 2010 the pond EC was of the order of $100-500 \mu \mathrm{S} \mathrm{cm}^{-1}$, meaning the pond would be classified as fresh. The salt mass in the pond during this period was of the order of $500 \mathrm{~kg}$. Average conditions are exemplified by 1994 in Fig. 5. Here, the pond water volume increases in springtime following the snowmelt runoff from the adjacent uplands which causes a strong dilution. Over the summer months, the water levels drop due to a combination of infiltration and evaporation, and the salinity increases, due to evaporation. The mass of salt in the ponds steadily decreases, due to infiltration, and salts accumulate in the soils, especially in the saline ring around the pond (Hayashi et al., 1998b; Heagle et al., 2007; Nachshon et al., 2013). This is the steady salt cycle that operates continuously in the closed drainage basins of the prairies. However, to complete the cycle, salts must re-enter the pond at some point. The re-entry mechanism is harder to observe, but is thought to be associated with the flushing of near-surface salts from the soil by the snowmelt via surface or shallow subsurface pathways (Hayashi et al., 1998b). It is also possible that diffusion might play a role in returning salts to the ponds from the soils.

During the two wet years associated with exceptional snowmelt (1997 and 2007) the pond salinity was unexceptional, and pond salt mass was only marginally elevated. This is consistent with the snowmelt re-entry mechanism, but shows that this effect has a negligible and short-lived impact on the salt cycle.

The first wet year associated with extreme summer rainfall (which fell in that year) was 2010, and here a dramatic increase in pond salinity (EC rose from 261 to $801 \mu \mathrm{S} \mathrm{cm}^{-1}$ ) and salt mass ( $M_{\text {salt }}$ rose from 260 to $1350 \mathrm{~kg}$ ) was initiated, making the pond moderately brackish. In 2011, water levels were even higher, but this was largely due to the antecedent water levels from the previous year. After the melt event and through the summer, the water level dropped, whilst the salt mass increased, perhaps suggesting that the pond was functioning as a flow-through pond during this period (Nachshon et al., 2013), with a highly saline inflow at some point, and a more diluted outflow somewhere else. This will be explored further below. The EC during this period steadily rose from 527 to $846 \mu \mathrm{S} \mathrm{cm}^{-1}$ due to evaporation. Finally in 2012, which had both high antecedent water levels and salt mass, and extreme high summer rainfall, the salt mass and salinity continued to rise rapidly to unprecedented levels (EC up to $1061 \mu \mathrm{S} \mathrm{cm}^{-1}$, salt mass peaking at $3800 \mathrm{~kg}$ ).

\subsection{Changes in water chemistry in a terminal recharge pond}

The major ion analysis of pond 109 water over the years of 2007-2009 and 2012 reveals a significant change in the cation composition of the pond water. In 2007-2009 the major cations in the pond water were $\mathrm{Ca}, \mathrm{Mg}$, and $\mathrm{Na}$ with molar fractions of approximately 60,35 , and $5 \%$, respectively (Fig. 6). In 2012, at the end of the measured wet period, the pond water cation composition was of 35,50 , and $15 \%$ for $\mathrm{Ca}, \mathrm{Mg}$, and $\mathrm{Na}$, respectively, caused by enrichment of the pond water with $\mathrm{Mg}$ and $\mathrm{Na}$. This enrichment is likely due to two reasons: (1) reverse flows into the pond of the saline-ring pore water, that is enriched in $\mathrm{Mg}$ and $\mathrm{Na}$ (St. Arnaud, 1979); and (2) dissolution and migration of mirabilite $\left(\mathrm{Na}_{2} \mathrm{SO}_{4} \cdot 10 \mathrm{H}_{2} \mathrm{O}\right)$, bloedite $\left(\mathrm{Na}_{2} \mathrm{Mg}\left[\mathrm{SO}_{4}\right]_{2} \cdot 4 \mathrm{H}_{2} \mathrm{O}\right)$, and epsomite $\left(\mathrm{MgSO}_{4} \cdot 7 \mathrm{H}_{2} \mathrm{O}\right)$, which are the more soluble salts that persists in the prairie tills. Under normal conditions, these salts accumulate at the more distant parts of the uplands, away from the ponds, according to the Hardie-Eugster model (Miller et al., 1989; Miller and Brierley, 2011; Skarie et al., 1987; Timpson et al., 1986; Nachshon et al., 2013). The fact that under high summer rainfall these cations migrate into the pond indicates subsurface water flows from high and distant parts of the uplands that flush these salts from the subsurface into the pond. Future studies may further explore the source of saline water entering the ponds and quantify the amount of salts contributed from the saline-ring pore water and the more distant parts of the uplands.

\subsection{Groundwater-surface water interactions}

The measurements obtained by the piezometers (Fig. 1) indicate the direction of subsurface exchanges between pond 109 and the upland to the north of the pond. Figure 7 contrasts differences in the magnitude and direction of this gradient with changes in the mass of salt $\left(M_{\text {salt }}\right)$ in the pond water, for 

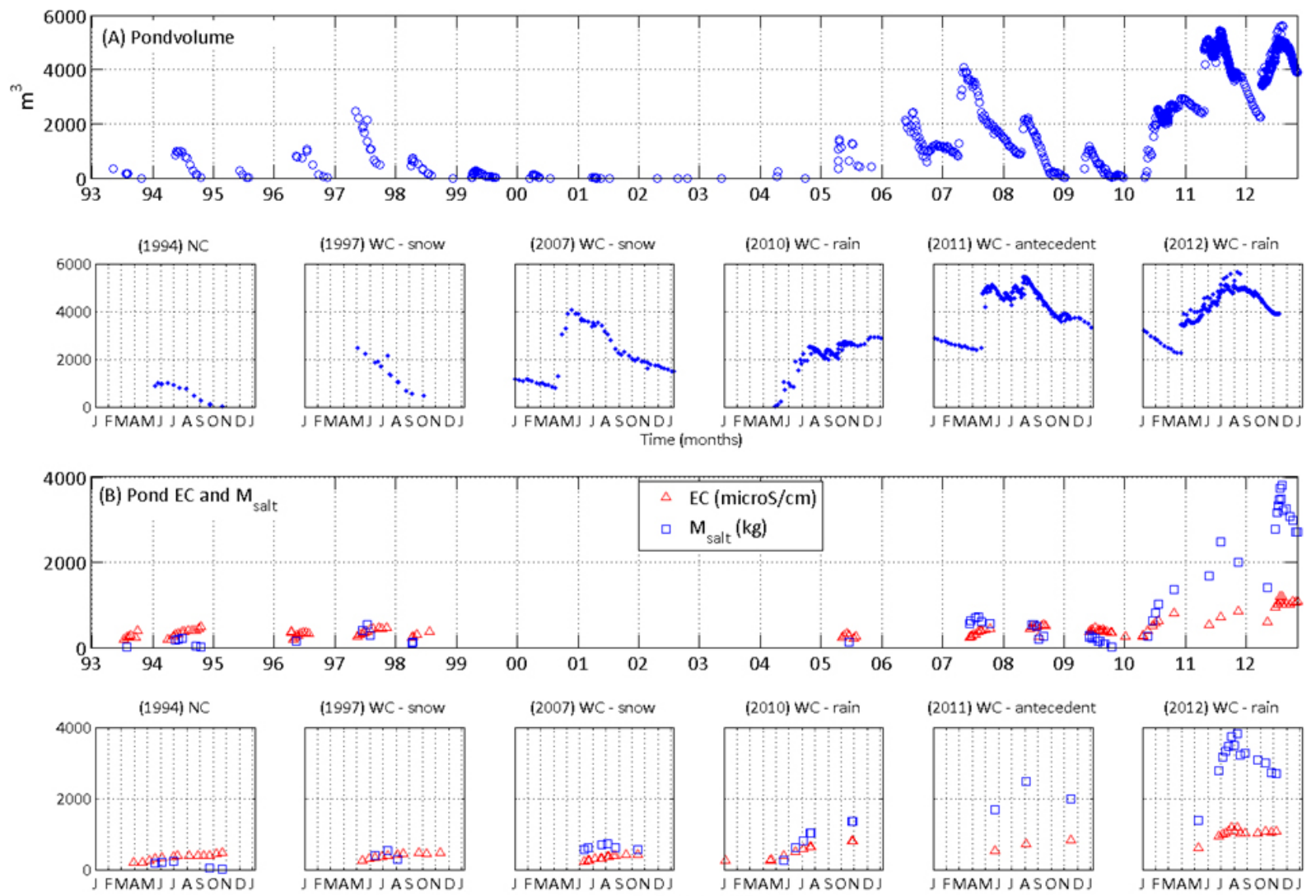

(2012) WC - rain

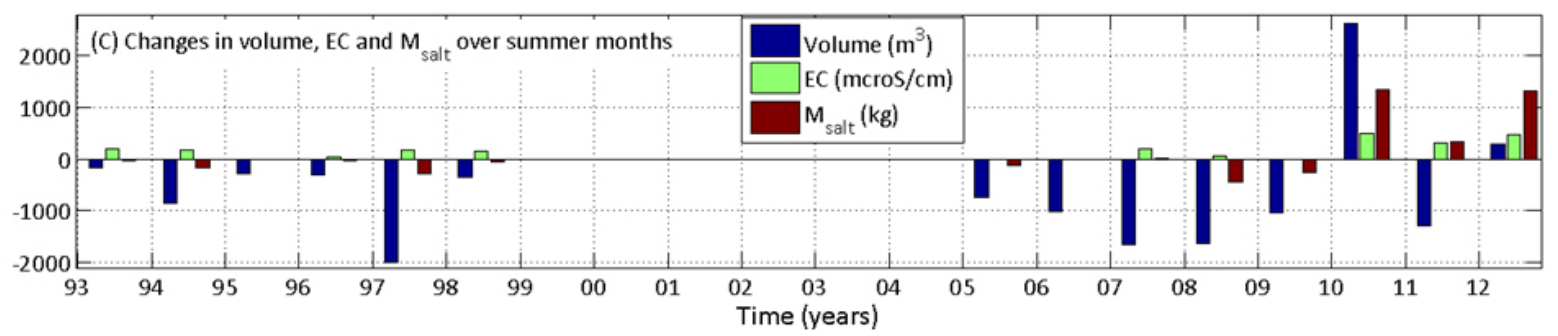

Fig. 5. (A) Pond 109 volume; (B) measured EC and calculated $M_{\text {salt }}$; and (C) summertime changes in volume, EC and $M_{\text {salt }}$ of the pond. Separated (lower) figures in (A) and (B) are zoomed for selected years with various climatic conditions, where NC and WC stand for normal and wet meteorological conditions, respectively.

2008-2012. It can be seen that most of the time the hydraulic head gradient is from the pond to the uplands, indicating flow out of the pond. However, on several occasions, most prominently in the summer of 2010, the hydraulic head gradients were reversed, indicating fluxes from the uplands back into the pond, with the potential of transporting dissolved salts from the uplands into the pond. For more than $85 \%$ of the data points, these data behave consistently - that is an inflow to the pond is associated with an increasing salt mass and an outflow from the pond is associated with a diminishing salt mass. However, for $\sim 15 \%$ of the data points, a positive buildup of salt mass coincided with apparent flow out of the pond. These anomalous measurements (red symbols in Fig. 7) were observed mainly in the summer of 2012.
These points can be explained either as slow mixing within the pond, or, again, as evidence of non-uniform inflows and outflows to/from the pond, where one side of the pond receives water from upper areas while other sides of the pond may infiltrate down and away of the pond.

\subsection{Salinity of the riparian zone}

Mini-observation wells combined with EM38 readings provide estimates of EC of pore water around pond 108A (the end of the transect discussed below) and pond 109 (the terminal recharge pond discussed above) (Fig. 8). Around pond 109 average $\mathrm{EC}$ was $3342 \mu \mathrm{S} \mathrm{cm}^{-1}$ with a maximum EC of $5500 \mu \mathrm{S} \mathrm{cm}^{-1}$ in the eastern side of the pond. The pore water was 3 to 5 times more saline than the pond 


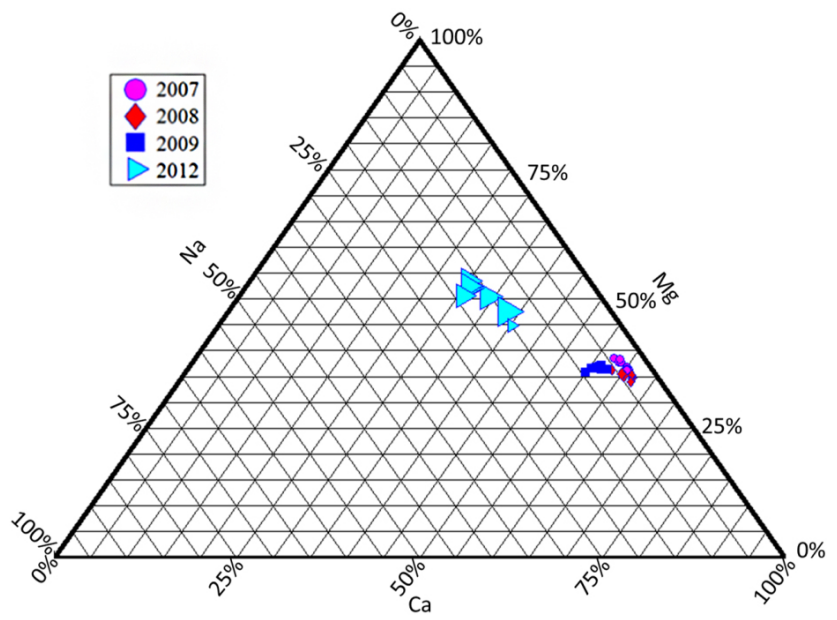

Fig. 6. Major cations molar fraction in pond 109 for the years 20072009 and 2012. Marker size is proportional to the pond EC.

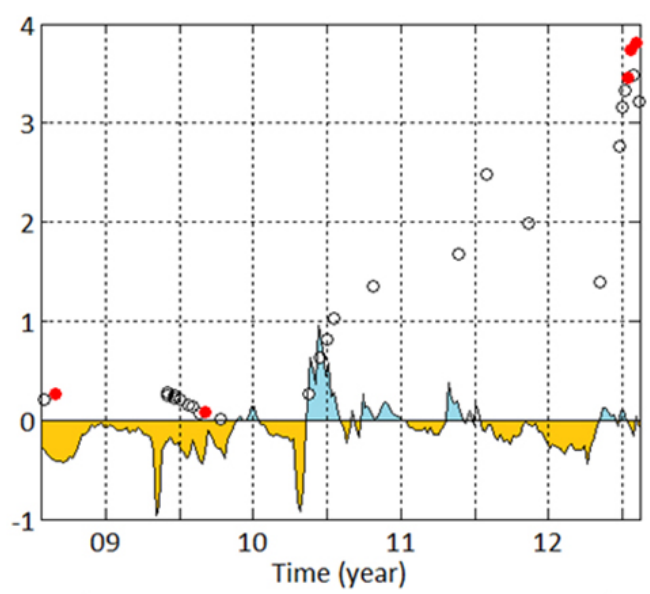

\begin{tabular}{|l}
\hline Slope minus pond water levels $(\mathrm{m})$ \\
$-\quad$ Pond 109 salt mass $\left(\times 10^{3} \mathrm{~kg}\right)$ \\
$\square$ Subsurface flow into pond \\
$\square$ Subsurface flow out of pond
\end{tabular}

Fig. 7. (A) Water level differences between upland piezometer and pond 109 and $M_{\text {salt }}$. Red symbols indicate the anomalous points, where a disparity was observed between the direction of the subsurface water flows a the north end of pond 109 and the changes in $M_{\text {salt }}$.

water, which was $1020 \mu \mathrm{S} \mathrm{cm}^{-1}$ at the time of measurement. For pond 108A average EC at pore water around the pond was equal to $3200 \mu \mathrm{S} \mathrm{cm}^{-1}$ with maximum $\mathrm{EC}$ of $4000 \mu \mathrm{S} \mathrm{cm}^{-1}$ in the southern side of the pond. These values are $\sim 1.5$ times more saline than the pond water (equal to $2300 \mu \mathrm{S} \mathrm{cm}^{-1}$ ). It follows that exchanges of water between the pond and soils/groundwater are far more efficient at transporting salts by advection into the pond than out. For example, for pond 109 , in order to remove the salts added to

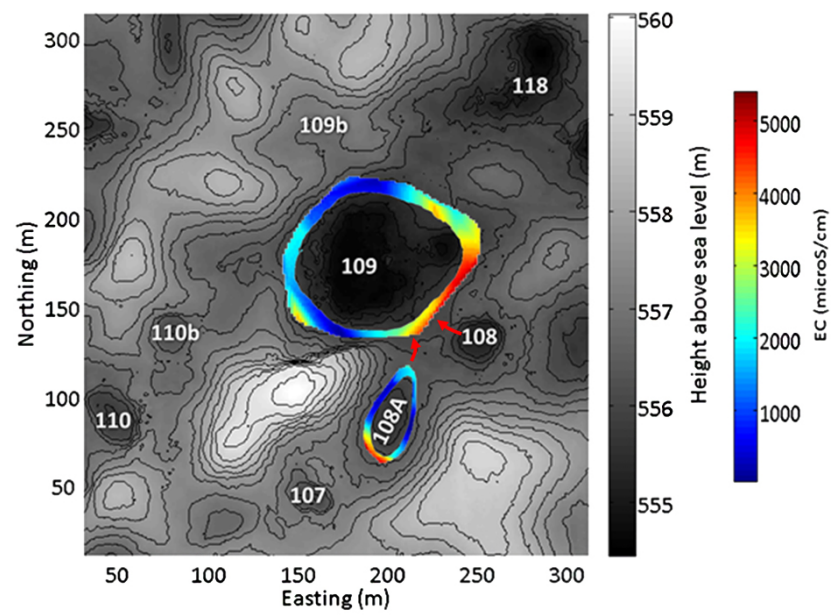

Fig. 8. Salinity around ponds 109 and 108A. Red arrows indicate the direction and location of overland flow during the observation period.

the pond for every volume unit of inflow (i.e. exfiltration of groundwater), 3-5 times more volume units of outflow (i.e. infiltration of pond water) would be required. It is also evident from Fig. 8 that the spatial distribution of salt in the saline ring is non-uniform, with distinctive regions of high and low salt concentrations. We speculate that this may be related to the slope steepness and the spatial distribution of the elevated-adjacent ponds. However, this hypothesis and the associated processes should be explored in future studies.

\subsection{Response to summer rainfall along a transect}

Figure 9 shows the water levels and EC data observed along a transect between ponds 107 (shown on the left in Fig. 9b and c, where $x=0 \mathrm{~m}$ ) and 108A (shown on the right in Fig. 9b and c, where $x=35 \mathrm{~m}$ ) for a 20-day period in July 2012, which included a large rainfall event on 15 July. For the first two observation times (5 and 6 July, row 1 and 2 in Fig. 9), conditions were relatively dry. The water table pattern reflects the general conceptual model for the prairies (Fig. 6 in van der Kamp and Hayashi, 2009), whereby both ponds are close to equilibrium with the adjacent groundwater, which drops lower beneath the uplands. With respect to salinity; under these conditions the highest EC values were measured in the pore water close to pond 108A, which is the local saline ring of this pond. On 11 July (row 3 in Fig. 9), a minor rainfall event resulted in a moderate increase in the water table, which also allowed for more points to be sampled for EC. The only significant difference in EC was measured at $x=31 \mathrm{~m}(\sim 5 \mathrm{~m}$ from pond $108 \mathrm{~A})$, where EC readings rose from $\sim 2000 \mu \mathrm{S} \mathrm{cm}^{-1}$ to well over $6000 \mu \mathrm{S} \mathrm{cm}^{-1}$. This may indicate leaching of salts from upper parts of the unsaturated profile by the infiltrating rain water, but the affect appears highly localized above the saline ring of pond 108A. The next set of measurements on 19 July (row 4 in Fig. 9), followed a 

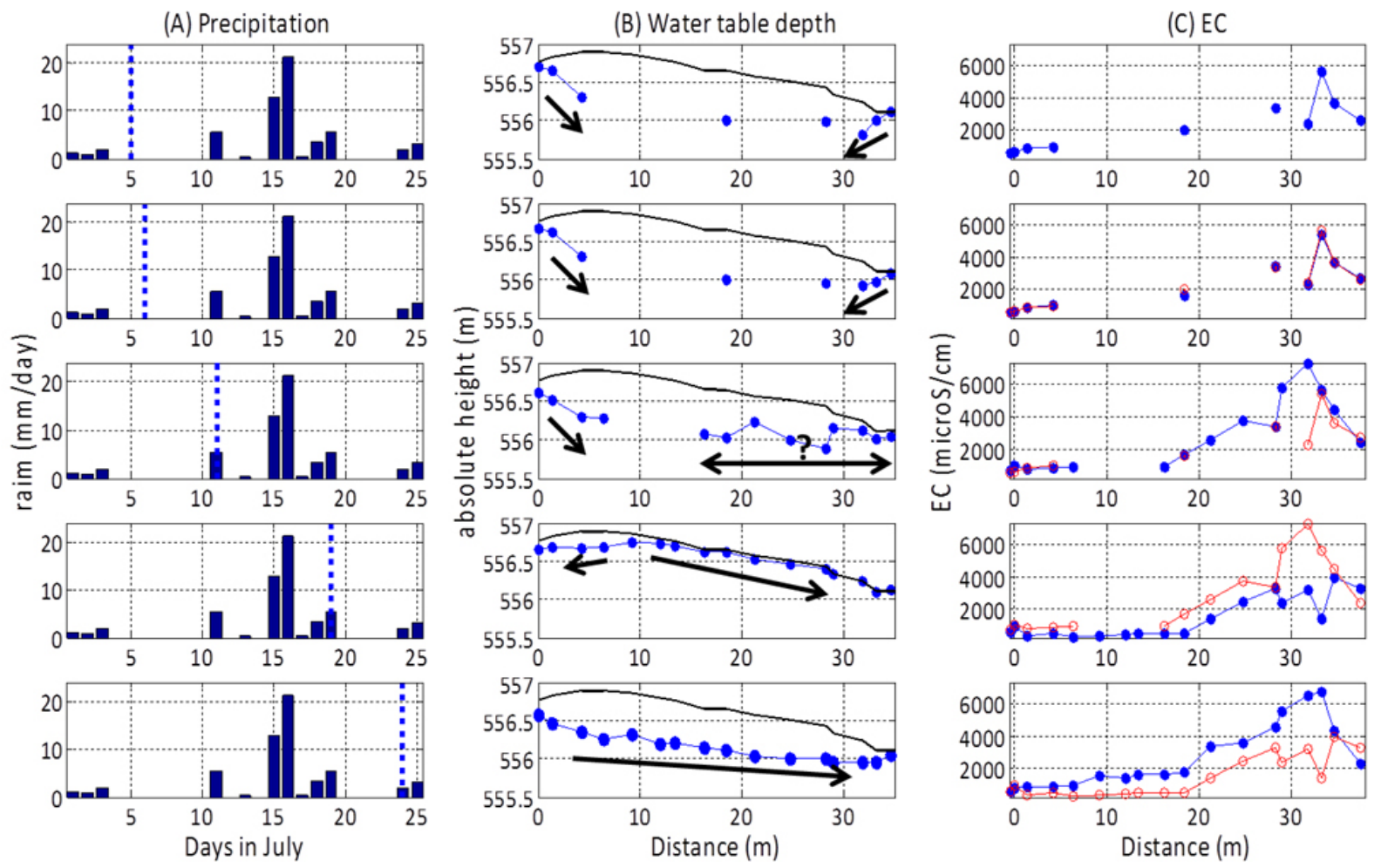

Fig. 9. Measured precipitation (A); water table depth (B); and EC (C) along the 107-108A transect. The dashed lines in (A) indicate the day on which measurements were taken for $(\mathbf{A}),(\mathbf{B})$, and $(\mathbf{C})$ in the same row. In $(\mathbf{B})$ the black line is the ground surface and the blue curve is the location of the water table. Arrows indicate groundwater flow directions. In (C) blue lines indicate the measured EC along the transect. Red curves are measured EC for the previous measurement, to emphasize the change of EC with time.

large rain event on 15 and 16 July. The water table came to ground surface along much of the transect, and in these parts of the transect seepage of the water above ground surface was visibly observed. We can be certain that this was a saturation excess mode of runoff, and moreover no fill-and-spill of pond 107 into pond 108A was observed. Since the miniobservation wells were screened along their entire length, it is not possible to determine whether this was local perching, or groundwater recharge bringing the water table up to the surface, but due to the high infiltration capacity of the fractured till, the latter is believed to be more plausible. During this period the EC was reduced across the transect, due to dilution, except on the right-hand edge, closest to pond 108A. This edge would have received much of the salt being flushed laterally from the transect, as the head gradients show, and hence here the EC rose up from $\sim 2620$ to $3310 \mu \mathrm{S} \mathrm{cm}^{-1}$. For the final set of measurements on 24 July (row 5 in Fig. 9), taken after 5 days with no rain, the water table depth declined along the entire transect, but not quite to depths as low as the antecedent levels (rows 1 and 2 in Fig. 9). Hydraulic gradients from the earlier observations showed two ponds that were disconnected from one another, whereas the later observations show a more-or-less continuous hydraulic gradient from pond 107 to pond 108A, suggesting the ponds were then connected, albeit perhaps temporarily. As the pulse of rain water left the profile, the EC profile returned to levels very similar to the antecedent conditions. Adjacent to pond 108A the salinity dropped again, probably in response to mixing with other fresher water in the pond.

\subsection{Conceptual model}

As described above and in concurrence with the conceptual model of Nachshon et al. (2013), all the evidence indicates that the extremely rainy summers have a major role in salt transport from the uplands to the wetlands. While both extremely snowy winters and rainy summers elevate the pond water levels, only the latter results in increasing dissolved salt mass in the ponds. This disparity is related to the differences in the hydrological pathways associated with snowmelt and rainfall. Surface runoff likely dominates in frozen conditions. There are three types of subsurface pathways that can occur in the prairies, at different times and in different places, as indicated in Fig. 10. These are: (1) isolated ponds, which only lose water to the immediate riparian zone; (2) subsurface connectivity between adjacent ponds where the elevated pond is feeding the lower-lying pond; and (3) mounded groundwater levels beneath the upland, with a groundwater divide developing and subsurface flows laterally feeding all 


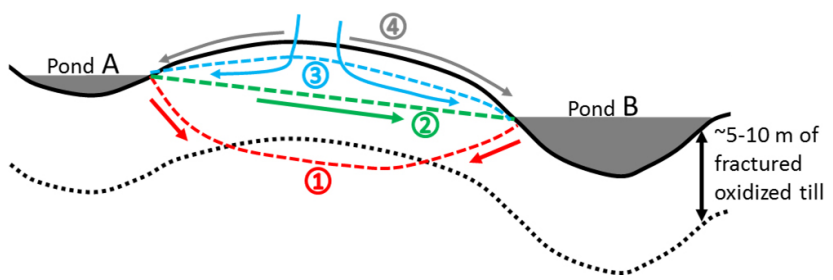

Fig. 10. Conceptual water flow paths (arrows) between two adjacent ponds in the prairie pothole region. Red line and arrows (1) indicate groundwater levels and flow paths, respectively, for dry conditions. Green line and arrows (2) indicate wet conditions where pond A is feeding pond B via the subsurface effective transmission zone. Blue lines and arrows (3) show wetter conditions with a mounded water table and flow diverging from a groundwater divide between the ponds. Gray arrows (4) show typical flow paths for snowmelt water over frozen soils, away from the topographic divide.

adjacent ponds. Scenario 1 is typical for the dry conditions of the prairies. Scenario 2 may happen under wetter conditions, where the pond levels are high and the groundwater levels are elevated above the upper boundary of the nonfractured till. Under these conditions the elevated pond is feeding the lower-lying pond with water and dissolved salts from the uplands. This kind of connectivity between adjacent ponds depends on the ponds' relative water levels and the thickness of the weathered, fractured till layer. Both extreme rainy summers and snowy winters may result in this kind of connectivity by filling up the ponds to extremely high levels. However, for the snow-associated wet conditions, the duration of the high water levels in the ponds is limited to a few weeks only during springtime, as shown in Fig. 5. For rainassociated wet conditions, the high water levels of the ponds may persist for a few months over an extremely rainy summer (Fig. 5). Consequently, the impact of wet conditions associated with rainfall on salt transport is much stronger compared to wet conditions associated with snowfall. Scenario 3 is typical for extreme rain-associated wet conditions, since this scenario is a result of rainwater infiltration through the uplands. Such a condition is not likely to be seen in snowassociated wet conditions, as the snowmelt water is flowing as surface runoff toward the depressions over the still-frozen soils of the uplands, with minimal vertical infiltration (gray arrows in Fig. 10).

\section{Conclusions}

Field measurements collected over the past 20 years from St. Denis in central Saskatchewan shed new light on salt dynamics of prairie wetlands. In concurrence with the conceptual model of Nachshon et al. (2013), it was shown that under wet conditions associated with rainy summers, large fluxes of salts from the subsurface are flushed into the ponds. The corresponding change in pond salinity (i.e. salt concentration) depends on the antecedent salinity, the volume of water flushed into the ponds and the salinity of the water flushed into the pond. However, the general tendency is quite uniform, with freshwater ponds becoming more saline, moderately brackish ponds remaining largely unchanged, and brackish ponds becoming diluted. Most of the time, however, summer rainfall is small compared with potential evaporation, and thus the dominant (or only) source of infiltration is depression-focused recharge of snowmelt beneath the ponds. Significantly, it was seen that wet conditions associated with this kind of infiltration, i.e. unusually snowy winters, had a negligible impact on the salt dynamics and pond salinization. Moreover, the rain-associated wet conditions lasted for much longer durations (months) compare to the snow-associated wet conditions (weeks), therefore increasing the potential impact of the unusual rain conditions on the subsurface salt transport processes.

The relatively high permeability of the top few meters of the prairie till results in a quick response in the upland subsurface storage that leads to relatively quick transport of salts from the upland subsurface to the ponds, on timescales of the order of a few days only. Even quicker responses in water flows and pond levels may occur by surface fill and spill events, but usually the surface waters are less saline than the pore water, thus salt transport is more limited under these conditions. The quick response in elevating shallow groundwater levels and the rapid changes in the pore water salinity following an extreme rain event, together with the fact that ponds that are well above the piezometric surface (such as pond 109) became salinized under rain-associated wet conditions suggests that the main water (and salt) flow path is through the top few meters of the soil and not through longer and more regional flow paths via the deep aquifer. However, further study is required to determine the exact subsurface flow paths of the infiltrating water as function of the hydrological and geological conditions.

It is hard to predict what the climatic conditions in the near and far future would be, but recent years' evidence, as well as climatic models, indicate that the variability of the climate is expected to increase, with a high chance of extreme rain periods, as well as extreme droughts (Frelich and Reich, 2009; Semenov and Stratonovitch, 2010). If a series of extremely wet years, where salt is being accumulated in the ponds, is followed by a severe drought, the high evaporation rates of the drought period will result in further increase in the pond salinity and eventually, all of the salts within the pond water will be precipitated, following the complete drying of the pond. This scenario may result in salt concentrations in the upper soil horizons of the wetlands at concentrations that were never measured before. Since both the wildlife of the prairies, as well as agricultural activities, depend on the wetlands' physical and chemical conditions, it is critical to improve our understanding of the geo-chemical processes and to be prepared to cope with salinization processes in the prairies due to climatic variability and change. 
Acknowledgements. This research was supported by the University of Saskatchewan Global Institute for Water Security. Any opinions, findings, and conclusions or recommendations expressed in this material are those of the authors and do not necessarily reflect the views of the sponsoring agencies. The authors would like to thank Dr. Goldhaber and two anonymous reviewers for their helpful reviews of the paper.

Edited by: W. Buytaert

\section{References}

Beaulieu, C. and Wittrock, V.: Climate reference station Saskatoon annual summary 2012, Saskatchewan Research Council Publication No. 10440-1E13, Saskatchewan Research Council, Saskatoon, Saskatchewan, 2013.

Berthold, S., Bentley, L. R., and Hayashi, M.: Integrated hydrogeological and geophysical study of depression-focused groundwater recharge in the Canadian prairies, Water Resour. Res., 40, W06505, doi:10.1029/2003WR002982, 2004.

Conly, F. M., Su, M., van der Kamp, G., and Millar, J. B.: A practical approach to monitoring water levels in prairie wetlands, Wetlands, 24, 219-226, 2004.

Dehaan, R. and Taylor, G. R.: Field-derived spectra of salinized soils and vegetation as indicators of irrigation-induced soil salinization, Remote Sens. Environ., 80, 406-417, 2002.

Euliss, N. H., LaBaugh, J. W., Fredrickson, L. H., Mushet, D. M., Laubhan, M. K., Swanson, G. A., Winter, T. C., Rosenberry, D. O., and Nelson, R. D.: The wetland continuum: a conceptual framework for interpreting biological studies, Wetlands, 24, 448458, 2004.

Frelich, L. E. and Reich, P. B.: Will environmental changes reinforce the impact of global warming on the prairie-forest border of central North America?, Front. Ecol. Environ., 8, 371-378, 2009.

Hayashi, M. and van der Kamp, G.: Simple equations to represent the volume-area-depth relations of shallow wetlands in small topographic depressions, J. Hydrol., 237, 1-2, 74-85, doi:10.1016/S0022-1694(00)00300-0, 2000.

Hayashi, M., van der Kamp, G., and Rudolph, D. L.: Mass transfer processes between a prairie pothole and adjacent uplands, 1: water balance, J. Hydrol., 207, 42-55, 1998a.

Hayashi, M., van der Kamp, G., and Rudolph, D.L.: Mass transfer processes between a prairie pothole and adjacent uplands, 2: chloride cycle, J. Hydrol., 207, 56-67, 1998b.

Heagle, D. J., Hayashi, M., and van der Kamp, G.: Use of solute mass balance to quantify geochemical processes in a prairie recharge wetland, Wetlands, 27, 806-818, 2007

Heagle, D. J., Hayashi, M., and van der Kamp, G.: Surfacesubsurface salinity distribution and exchange in a closed-basin prairie wetland, J. Hydrol., 478, 1-14, 2013.

Keller, C. K., van der Kamp, G., and Cherry, J. A.: Hydrogeochemistry of a Clayey Till: 1. Spatial Variability, Water Resour. Res., 27, 2543-2554, 1991.

Mekis, É. and Vincent, L. A.: An overview of the second generation adjusted daily precipitation dataset for trend analysis in Canada, Atmos.-Ocean., 49, 163-177, 2011.

Micklin, P.: The Aral sea disaster, Annu. Rev. Earth Planet. Sci., 35, 47-72, 2007.
Millar, J. B.: Wetland classification in Western Canada, Can. Wildl. Rep. Ser. 37, 1-38, 1976.

Miller, J. J. and Brierley, J. A.: Solonetzic soils of Canada: Genesis, distribution, and classification, Can. J. Soil Sci., 91, 889-902, 2011.

Miller, J. J., Pawluk, S., and Beke, G. J.: Evaporite mineralogy, and soil solution and groundwater chemistry of a saline seep from southern Alberta, Can. J. Soil Sci., 69, 273-286, 1989.

Nachshon, U., Ireson, A., van der Kamp, G., and Wheater, H.: Sulfate salt dynamics in the glaciated plains of North America, J. Hydrol., 499, 188-199, 2013.

Rengasamy, P.: World salinization with emphasis on Australia, J. Exp. Bot., 57,5, 1017-1023, 2006.

Rhoades, J. D., Sparks, D. L., Page, A. L., Helmke, P. A., Loeppert, R. H., Soltanpour, P. N., and Sumner, M. E.: Salinity: electrical conductivity and total dissolved solids, Methods of soil analysis, Part 3 - chemical methods, American Society of Agronomy, Madison, Wisconsin, 417-435, 1996.

Semenov, M. A. and Stratonovitch, P.: Use of multi-model ensembles from global climate models for assessment of climate change impacts, Clim. Res., 41, 1-14, 2010.

Shaw, D. A., van der Kamp, G., Conly, M., Pietroniro, A., and Lawrence, M.: The fill-spill hydrology of prairie wetland complexes during drought and deluge, Hydrol. Process., 26, 31473156, 2012.

Shook, K. R. and Pomeroy, J. W.: Memory effects of depressional storage in Northern Prairie hydrology, Hydrol. Process., 25, 3890-3898, 2011.

Skarie, R. L., Richardson, J. L., McCarthy, G. J., and Maianu, A.: Evaporite mineralogy and groundwater chemistry associated with saline soils in eastern North Dakota, Soil Sci. Soc. Am. J., 51, 1372-1377, 1987.

Spence, C. and Woo, M. K.: Hydrology of subarctic Canadian Shield: Soil-filled valleys, J. Hydrol., 279, 151-166, 2003.

St. Arnaud, R. J.: Nature and distribution of secondary soil carbonates within landscapes in relation to soluble $\mathrm{Mg}++/ \mathrm{Ca}++\mathrm{ra}-$ tios, Can. J. Soil Sci., 59, 87-98, 1979.

Stewart, R. E. and Kantrud, H. A.: Vegetation of prairie potholes, North Dakota, in relation to quality of water and other environmental factors, US Government Printing Office, Washington, D.C., USA, 1972.

Swanson, G. A., Winter, T. C., Adomaitis, V. A., and LaBaugh, J. W.: Chemical characteristics of prairie lakes in south-central North Dakota - their potential for impacting fish and wildlife, Technical Report 18, US Fish and Wildlife Service, Washington, D.C., USA, 1988.

Timpson, M. E., Richardson, J. L., Keller, L. P., and McCarthy, G.J.: Evaporite mineralogy associated with saline seeps in southwestern North Dakota, Soil Sci. Soc. Am. J., 50, 490-493, 1986.

Tyler, S. W., Munoz, J. F., and Wood, W. W.: The response of playa and sabkha hydraulics and mineralogy to climate forcing, Ground Water, 44, 329-338, 2006.

van der Kamp, G. and Hayashi, M.: Groundwater-wetland ecosystem interaction in the semiarid glaciated plains of North America, Hydrogeol. J., 17, 203-214, 2009.

Wheater, H. S., Jakeman, A. J., and Beven, K. J.: Progress and directions in rainfall-runoff modeling, in: Modeling change in environmental systems, John Wiley \& Sons, Chichester, UK, 101132, 1993. 
Wienhold, C. E. and van der Valk, A. G.: The impact of duration of drainage on the seed banks of northern prairie wetlands, Can. J. Bot., 67, 1878-1884, 1989.
Winter, T. C.: Hydrologic studies of potholes in the northern prairies, in: Northern prairie wetlands, Iowa State University Press, Iowa, USA, 17-54, 1989. 